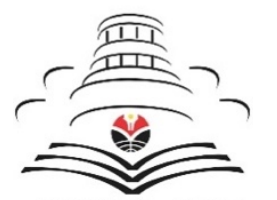

JURNAL UPI
JAPANEDU:

Jurnal Pendidikan dan Pengajaran Bahasa Jepang

http://ejournal.upi.edu/index.php/japanedu/index

\title{
Interactive Learning Medium Development for Learning Hiragana and Katakana
}

\author{
Desak Made Sri Mardani, I Wayan Sadyana, Putu Hendra Suputra \\ Japanese Language Department, Universitas Pendidikan Ganesha, Singaraja, Indonesia \\ desak.mardani@undiksha.ac.id
}

\begin{abstract}
A B S T R A C T
The ability of college students in X university to use Hiragana and Katakana letters is still weak due to the lack of practice in reading and using these letters in a word/sentence. The ability to use Hiragana and Katakana letters is not only about the ability to understand the order of writing and the differences in the strokes, but also to use Hiragana and Katakana in words/sentences. This research was a descriptive study using R \& D design based on the Four-D Model. In this study, three stages were carried out out of the four stages of the model. Questionnaires and interviews were used in this study as a method of data collection. Interviews also conducted to determine the needs of teachers and students, while questionnaire was used for expert judgement (expert appraisal) process consisting of learning media expert judgement and content expert judgement. The questionnaire data were analyzed descriptively to determine deficiencies in the media created. After going through the improvement phase, then a limited scale trial was conducted on 26 students. From the questionnaire data on the interactive media produced, it is known that overall, the media produced received excellent responses from students, wherein each assessment indicator also received a positive response as well. However, further studies are needed to find out how to implement the interactive media of Hiragana and Katakana in the learning process directly inside the classroom.
\end{abstract}

\section{K E Y W O R D S}

Expert appraisal; Hiragana; Interactive media; Katakana; R \& D design

First received: 16 August 2019

A R T I C L E I N F O

Available online: 20 June 2020

Final proof accepted: 4 March 2020

\section{PENDAHULUAN}

Media pembelajaran merupakan alat bantu dalam proses belajar mengajar yang memiliki fungsi untuk menyampaikan isi atau materi yang ingin disampaikan oleh pengajar, sehingga informasi/ilmu tersebut dapat dipahami oleh pembelajar. Dalam proses pembelajaran, penggunaan media pembelajaran merupakan salah satu faktor penentu keberhasilan pembelajar dalam menguasai materi pembelajaran. Hal tersebut dapat terlihat dari berbagai manfaat dalam penggunaan media pembelajaran yaitu: membuat konkret konsepkonsep yang abstrak, menghadirkan objek yang tidak mungkin dihadirkan di kelas, menampilkan objek yang terlalu besar atau terlalu kecil, serta 
memperlihatkan gerakan yang terlalu cepat atau lambat (Susilana \& Ruyana, 2009). Dengan demikian, media pembelajaran sebaiknya dikembangkan sesuai dengan materi/objek pembelajaran.

Pengembangan media pembelajaran dapat dilakukan oleh pengajar atau pengajar dapat menggunakan media yang telah dipasarkan di masyarakat. Pengajar merupakan kunci dalam peningkatan mutu pendidikan dan mereka berada di titik sentral dari setiap usaha reformasi pendidikan yang diarahkan pada perubahan-perubahan kualitatif. Seperti yang disampaikan oleh Elliot (2000) bahwa pengetahuan mendasar yang harus dikuasai oleh seorang pengajar adalah pengetahuan terkait bagaimana mengajar materi yang terbaik (Teaching (Pedagogical) Knowledge), tata cara dalam mengorganisasi dan strategi dalam menyampaikan materi (Subject Matter Knowledge) serta bagaimana materi ajar tersebut dapat dipahami oleh siswa (Teaching Subject Matter Knowledge). Oleh sebab itu seorang pengajar perlu memiliki kemampuan untuk menyediakan, mengolah dan mengatur pengetahuan agar tersampaikan dan diterima dengan baik oleh pembelajar, salah satunya dengan penggunaan media pembelajaran dalam proses belajar. Dengan penggunaan media pembelajaran, maka akan tercipta pembelajaran yang menarik. Media memberikan pengalaman belajar yang menarik melalui penyediaan akses yang lebih luas kepada pembelajar, salah satunya adalah media pembelajaran berbasis Teknologi Informasi dan Komputer (TIK). Media Berbasis TIK sudah banyak dikembangkan oleh pengajar dari segala bidang ilmu. Alessi dan Trollip (dalam Istiqlal, 2017) menyampaikan bahwa ratusan penelitian telah membuktikan bahwa penggunaan komputer pada pembelajaran lebih baik bila dibandingkan dengan penggunaan buku, pengajar, film, atau metode tradisional lainnya. Penelitian-penelitian tentang pendidikan telah membuktikan bahwa menggunakan komputer untuk mengajar lebih baik dari menggunakan buku, guru, film atau metode tradisional lainnya. Seperti yang disampaikan oleh Ghavifekr dan Rosdy (2015) bahwa integrasi TIK (proses belajar mengajar berbasis teknologi) efektif terhadap guru dan siswa dalam proses pembelajaran. Lebih lanjut Alessi dan Trollip (dalam Istiqlal, 2017) menyebutkan bahwa pengajar harus menggunakan berbagai macam bahan berbasis multimedia dan pendekatan dalam pembelajaran, serta menyediakan lingkungan belajar yang fleksibel sesuai dengan kebutuhan sebagian besar pembelajarnya. Oleh sebab itu, dengan bantuan komputer pengajar dapat menyediakan lingkungan belajar yang fleksibel sesuai dengan kebutuhan pembelajarnya.
Penguasaan pembuatan dan pemanfaatan media pembelajaran berbasis TIK sangat diperlukan terutama pada pembelajaran yang menekankan penjelasan proses. Program presentasi seperti Microsoft Power Point mampu menyajikan materi dengan instan dan mudah dengan berbagai template yang dimiliki, tetapi tidak mampu menunjukkan suatu materi yang mengandung sebuah proses (Mardani \& Suputra, 2016). Seperti misalnya dalam pembelajaran menulis huruf Jepang di Prodi Pendidikan Bahasa Jepang di salah satu universitas di Indonesia.

Kompetensi dalam menulis huruf Jepang di Prodi Pendidikan Bahasa Jepang tersebut sedikit berbeda bila dibandingkan dengan jurusan bahasa Jepang atau sastra Jepang yang ada di universitas lain. Menulis huruf Jepang khususnya Hiragana dan Katakana, diberikan pada mata kuliah Hyouki. Hyouki memiliki beban 2 sks dengan standar kompetensi agar mahasiswa memiliki kompetensi tentang keterampilan menulis huruf Jepang sesuai dengan aturan penulisan serta indah agar nantinya mampu mengajarkan siswa dengan baik dan benar pula, mengingat bahwa lulusan prodi merupakan calon pengajar.

Untuk mencapai kompetensi tersebut, dalam proses pembelajaran ditekankan penulisan huruf sesuai dengan aturan penulisan yang benar pada urutan penulisan huruf, serta keindahan huruf yang meliputi goresan huruf dan keseimbangan huruf. Dengan demikian penguasaan huruf Jepang tidak hanya menekankan pada penguasaan bentuk dan urutan penulisan huruf tetapi juga pada keindahan dari huruf itu sendiri (Mardani, 2012).

Untuk mencapai kompetensi seperti di atas maka penggunaan media pembelajaran berbasis TIK sangat membantu, seperti yang telah diperoleh dalam penelitian yang dilakukan oleh Mardani (2012) tentang penggunaan media visual berbasis TIK untuk meningkatkan kemampuan menulis huruf Hiragana dan Katakana. Dari hasil penelitian tersebut dapat diketahui bahwa media visual dapat membantu pembelajar dalam membedakan goresan dalam penulisan huruf Jepang, karena penggunaan media visual memungkinkan terlihatnya bentuk goresan dan urutan dalam penulisan. Pada penelitian tersebut digunakan warna yang berbeda pada goresan yang berbeda. Warna hitam untuk goresan yang ditulis berhenti di akhirnya (tomarimasu), warna biru untuk goresan yang ditulis lepas (haraimasu) serta warna hijau untuk goresan yang ditulis seperti percikan air (hanemasu). Selain media visual, pada penelitian tersebut digunakan pula metode tugas. Efektifitas media visual dan metode tugas tersebut terlihat dari peningkatan kemampuan menulis dan respon positif dari pembelajar terhadap penggunaan media visual. 
Penggunaan media visual dan metode tugas pada pembelajaran huruf Hiragana dan Katakana tersebut telah dilakukan secara berkesinambungan. Tidak hanya terbatas pada pembelajaran huruf Hiragana dan Katakana, namun juga digunakan pada pembelajaran huruf Kanji. Dalam hal penguasaan goresan dan urutan penulisan huruf, mahasiswa sudah tidak mengalami kendala. Tetapi ketika dihadapkan dengan pengaplikasian/penggunaan huruf dalam kata maupun kalimat, kemampuan mahasiswa masih kurang. Hal tersebut terlihat dari hasil pembelajaran huruf Hiragana dan Katakana pada mahasiswa tingkat satu di Prodi Pendidikan Bahasa Jepang, di salah satu universitas di Indonesia pada tahun ajaran 2018/2019. Dari tugas penulisan huruf yang menekankan pada keindahan dan urutan penulisan, dapat diketahui bahwa mahasiswa mampu melaksanakan dengan baik, begitu pula jika dimunculkan pada tes kecil di awal pelajaran. Tetapi, ketika mahasiswa dihadapkan pada penulisan huruf dalam sebuah kata maupun kalimat terlihat beberapa mahasiswa kurang menguasai huruf.

Pengajar merasakan kekurangan dalam penggunaan media visual sehingga memerlukan media yang lainnya. Media pembelajaran dapat dikelompokkan menjadi tiga kategori yaitu (1) media penyaji; (2) media objek; (3) media interaktif. Media pembelajaran interaktif dapat didefinisikan sebagai kombinasi dari berbagai media yang dikemas (diprogram) secara terpadu dan interaktif untuk menyajikan pesan pembelajaran tertentu (Purwanto \& Kusnandar dalam Lia, 2015). Media interaktif menuntut pembelajar untuk berinteraksi dengan media tersebut selama proses pembelajaran. Susilana dan Riyana (2009) mengungkapkan terdapat tiga jenis interaksi dalam penggunaan media interaktif, meliputi:

a. Pembelajar berinteraksi dengan sebuah program, contoh ketika mengisi blanko pada bahan belajar terprogram;

b. Pembelajar berinteraksi dengan mesin, contoh mesin pembelajaran, simulator, laboratorium bahasa, komputer atau kombinasi yang berbentuk video interaktif;

c. Mengatur interaksi antara pembelajar secara teratur tapi tidak terprogram, contoh pada permainan pendidikan atau simulasi yang melibatkan pembelajar dalam kegiatan atau masalah yang mengharuskan mereka untuk membalas serangan lawan atau bekerjasama dengan teman sekelompok dalam memecahkan masalah.

Purwanto dan Kusnandar (dalam Lia, 2015) menjelaskan bahwa program multimedia interaktif memiliki sejumlah kelebihan dibanding dengan media lainnya, yaitu:
1) Fleksibel, artinya pemberian kesempatan untuk memilih isi setiap bidang yang disajikan dan juga fleksibel dalam waktu dan penggunaannya.

2) Self-pacing, artinya bersifat melayani kecepatan belajar individu.

3) Content-rich, artinya program menyediakan informasi yang cukup banyak.

4) Interaktif, artinya program memberikan kesempatan kepada pengguna untuk memberikan respon yang akhirnya akan direspon oleh multimedia.

5) Individual, artinya program sudah dirancang dan disediakan untuk memenuhi minat kebutuhan individu.

Dengan memahami berbagai kelebihan dari media pembelajaran interaktif tersebut, pengembangan media pembelajaran interaktif dapat dilakukan untuk memfasilitasi pembelajaran seperti halnya pembelajaran huruf Hiragana dan Katakana.

Media interaktif yang diperlukan oleh pengajar adalah media yang mampu digunakan dalam proses penguasaan huruf Hiragana dan Katakana, yang bukan hanya memunculkan urutan dan goresan tulisan. Media pembelajaran interaktif yang bukan hanya sekedar pengenalan huruf dan cara penulisannya saja (seperti dilakukan sebelumnya dengan media visual) tetapi mengarah pada contoh penggunaan huruf tersebut serta latihan-latihan yang mampu merangsang kemampuan pembelajar untuk mengingat huruf dengan tepat dan cepat. Oleh sebab itu, sangat penting dilakukan pengembangan media pembelajaran interaktif untuk penguasaan huruf Hiragana dan Katakana.

Terkait pengembangan media pembelajaran interaktif sudah banyak dilakukan oleh peneliti lain pada segala bidang ilmu. Seperti misalnya pembuatan media interaktif pembelajaran bahasa Inggris dalam mengenalkan huruf dan membaca untuk anak SD yang dilakukan oleh Maesaroh dan Malkiah (2015). Media tersebut diketahui mampu menambah pengetahuan dan kemampuan dalam berbahasa Inggris dalam level anak kelas satu sekolah dasar. Terkait pembelajaran bahasa Inggris di tingkat $\mathrm{SD}$, sebelumnya telah dikembangkan pula media interaktif pembelajaran bahasa Inggris untuk jenjang kelas dua SD oleh Sari dan Sasongko (2013). Pengembangan media interaktif ini untuk memudahkan penyampaian materi atau pelajaran kepada siswa kelas dua SD.

Dari hasil pengembangan tersebut dapat diketahui bahwa dengan media pembelajaran interaktif, pembelajaran lebih menarik dan pesan/materi dapat tersampaikan dengan baik. Dengan melihat betapa pentingnya penguasaan huruf Hiragana dan Katakana bagi pembelajar pemula, maka diperlukan sebuah media interaktif 
yang mampu membantu pembelajar agar dapat menguasai huruf tersebut dengan benar dan cepat sesuai dengan aturan penulisan huruf Jepang. Hal tersebut menjadi sangat penting mengingat penguasaan huruf Jepang dalam hal menulis yang sesuai dengan aturan menjadi keunggulan di Prodi Pendidikan Bahasa Jepang di salah satu universitas di Indonesia yang menjadi sampel dalam penelitian ini. Pengembangan media ini dirasa sangat membantu dalam proses pembelajaran huruf Hiragana dan Katakana baik dari pihak pengajar maupun pembelajar. Dengan penelitian ini, maka salah satu kompetensi yang ingin dimiliki oleh lulusan Prodi Pendidikan Bahasa Jepang tersebut akan tercapai.

\section{METODE PENELITIAN}

Penelitian ini merupakan penelitian deskriptif dengan menggunakan rancangan R \& D yaitu Four$D$ Model dari Thiagarajan, S., dkk (1974). Menurut Sutedi (2009) penelitian deskriptif dilakukan untuk menggambarkan, menjabarkan, suatu fenomena yang terjadi saat ini dengan menggunakan prosedur ilmiah untuk menjawab masalah secara aktual. Berdasarkan Four-D Model maka dilakukan beberapa tahapan dalam penelitian.

Pada tahap pertama (tahap Define) dilakukan analisis kebutuhan dari sisi pengajar dan pembelajar. Dari hasil analisis diketahui bahwa diperlukan media yang bukan saja mampu memperlihatkan urutan penulisan dan goresan tetapi juga memberikan contoh penggunaan huruf pada sebuah kata.

Setelah tahap pertama selesai dilanjutkan dengan tahap kedua (tahap Design), dimana pada tahap ini hasil analisis pada tahap satu direalisasikan menjadi media pembelajaran yang memang dibutuhkan oleh dosen pengampu mata kuliah Hyouki yang disesuaikan pula dengan tuntutan universitas yaitu penggunaan teknologi informasi dalam pembelajaran. Dilakukan pembuatan prototipe dari media interaktif huruf Hiragana dan Katakana. Pada proses pembuatan dipergunakan Adobe Flash CS6.

Pada tahap ketiga (tahap Develop) dilakukan uji ahli (Expert appraisal) yang terdiri dari uji ahli media pembelajaran dan uji ahli isi. Feedback dari ahli digunakan untuk memperbaiki agar bahan pembelajaran lebih tepat, efektif, bermanfaat, serta memiliki teknik yang berkualitas. Setelah dilakukan uji ahli, media yang sudah diperbaiki berdasarkan masukan ahli memasuki tahap Developmental testing. Pada tahap ini dilakukan ujicoba pada skala terbatas kepada mahasiswa agar mengetahui respon mereka terhadap media yang dibuat. Tahap ketiga (tahap
Develop) ini merupakan tahap pengukuran efektivitas media pembelajaran interaktif huruf Hiragana dan Katakana.

Pada penelitian ini, tahap ke empat (Disseminate/penyebaran) tidak dilakukan mengingat keterbatasan waktu penelitian.

Dalam penelitian ini, subjek penelitian adalah dosen pengampu mata kuliah Hyouki di Prodi Pendidikan Bahasa Jepang, di salah satu universitas di Indonesia, serta mahasiswa. Sedangkan objek penelitian ini adalah media pembelajaran interaktif huruf Hiragana dan Katakana.

Dalam hal teknik penelitian, pada tahap pertama dilakukan wawancara terhadap pengajar mata kuliah Hyouki serta beberapa mahasiswa untuk mengetahui media seperti apa yang dibutuhkan oleh pengajar dan pembelajar. Pada tahap ketiga (tahap Develop) yaitu uji ahli (Expert appraisal) yang terdiri dari uji ahli media pembelajaran dan uji ahli isi, dua orang ahli akan diberikan angket terkait penilaian terhadap media yang dihasilkan. Data angket tersebut dianalisis secara deskriptif untuk mengetahui kekurangan dalam media yang dibuat. Setelah melewati tahap perbaikan, dilakukan ujicoba dalam skala terbatas terhadap 26 orang mahasiswa, Mahasiswa diberikan angket untuk melihat respon mereka terhadap media yang dihasilkan, terbatas pada tampilan media dan kejelasan goresan huruf. Data dari angket tersebut kemudian dianalisis. Adapun tahapan yang dilakukan dalam analisis data angket adalah sebagai berikut.

Menghitung interpretasi skor pada masingmasing pernyataan dengan penghitungan sebagai berikut:

$$
\text { Interval }(I)=\frac{\text { Jumlah total skor pertanyaan }}{\text { Jumlah total skor maksimal pertanyaan }} \times 100 \%
$$

Menentukan kategori respon pembelajar (lihat Tabel 1) terhadap media dengan menggunakan kriteria respon yang diungkapkan oleh Khabibah (dalam Yamasari, 2010).

Tabel 1: Kategori respon pembelajar.

\begin{tabular}{|l|l|}
\hline \multicolumn{1}{|c|}{ Persentase } & \multicolumn{1}{c|}{ Kategori } \\
\hline $\mathrm{I} \geq 85 \%$ & Sangat Positif \\
\hline $70 \% \leq \mathrm{I} \leq 85 \%$ & Positif \\
\hline $50 \% \leq \mathrm{I} \leq 70 \%$ & Kurang Positif \\
\hline $\mathrm{I}<50 \%$ & Tidak positif \\
\hline
\end{tabular}




\section{HASIL DAN PEMBAHASAN}

\section{Pengembangan Media Interaktif}

Dari hasil penelitian diketahui bahwa dalam pengembangan media interaktif perlu penambahan kosakata sebagai bahan latihan untuk pembelajar dalam belajar huruf Hiragana dan Katakana.

Pada pembuatan media pembelajaran interaktif ini digunakan Adobe Flash CS6, hal ini untuk memudahkan pembuatan urutan penulisan huruf. Mengacu pada hasil penelitian Mardani (2012), penggunaan warna yang berbeda pada goresan pembentuk huruf dapat membantu pembelajar menghasilkan huruf yang indah, maka pada pengembangan media ini juga digunakan warna yang berbeda pada masing-masing goresan. Adapun goresan dasar yang terdapat pada huruf Hiragana dan Katakana meliputi haraimasu (goresan dengan melepas pada akhir tulisan), tomarimasu (goresan dengan menghentikan tangan), hanemasu (goresan seperti percikan air). Goresan-goresan tersebut menggunakan warna berbeda seperti Gambar 1.

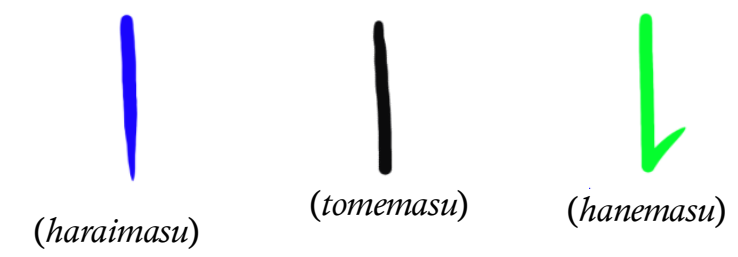

Gambar 1: goresan dasar yang terdapat pada huruf Hiragana dan Katakana.

Setelah prototipe media dihasilkan, dilakukan uji ahli media dan ahli isi, di mana diperoleh beberapa masukan. Adapun masukan yang diberikan oleh ahli lebih pada contoh kosakata yang digunakan serta tata letak kosakata tersebut dalam tampilan layar. Berdasarkan masukan dari ahli tersebut maka kosakata yang digunakan lebih banyak menggunakan kata benda dan merupakan kosakata yang berada di lingkungan pembelajar/mahasiswa. Hal ini untuk memudahkan pembelajar dalam memahami kosakata yang diberikan sehingga mereka dapat secara langsung menghubungkan antara tulisan dan makna kosakata tersebut. Untuk beberapa kosakata digunakan kosakata dari kata kerja. Kata kerja yang digunakan terbatas pada kata kerja yang sering dilakukan/digunakan oleh pembelajar, sehingga pemaknaan kata pun akan lebih mudah. Dalam hal tata letak kosakata, pada setiap tampilan layar dimunculkan beberapa kosakata dengan pemberian jarak yang sesuai agar pembelajar dapat melihat dengan baik contoh kata yang diberikan. Dengan memberikan hanya beberapa kosakata dalam satu tampilan layar diharapkan pembelajar tidak merasa terbebani.

Adapun media interaktif yang dihasilkan dalam pengembangan ini seperti terlihat pada penjelasan berikut.

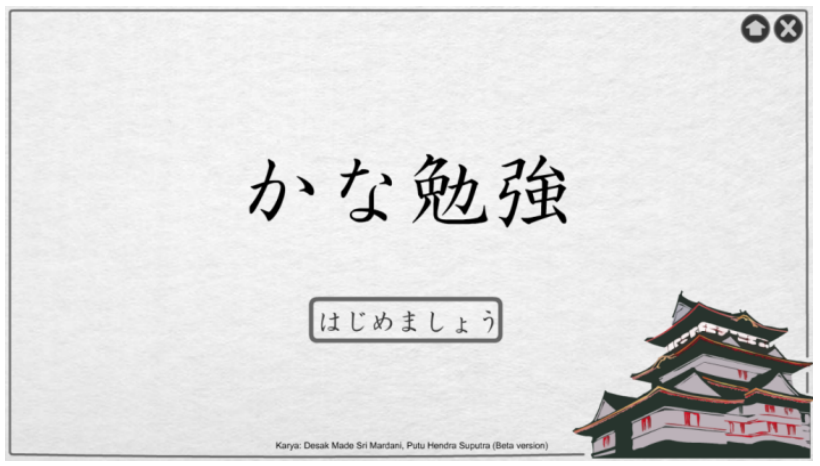

Gambar 2: Desain latar yang sederhana.

Pada media digunakan desain latar yang sederhana (Gambar 2). Hal ini dimaksudkan agar pembelajar menjadi fokus terhadap huruf Hiragana dan Katakana dalam pembelajaran, tanpa gangguan dari latar belakang yang berlebihan. Letak judul, silabel ataupun contoh kosakata dan kalimat disesuaikan dengan jumlah kemunculannya di satu layar. Hal tersebut untuk memanfaatkan ruang dengan baik, sehingga tampilan layar terlihat rapi dan memudahkan pembelajar untuk melihat dan membedakan huruf yang muncul. Mengingat banyaknya huruf Hiragana dan Katakana yang mirip satu dengan lainnya sehingga menyebabkan pembelajar kesulitan dalam membedakannya. Seperti yang ditunjukkan dalam penelitian yang dilakukan oleh Listriani, Lispridona, dan Silvia (2018) bahwa pembelajar kesulitan dalam membedakan huruf Hiragana yang mirip bentuknya.

Setelah tombol ‘はじめましょう' diklik maka akan muncul tampilan Gambar 3. Masing-masing bagian 書き方，ひらがな dan かたかな akan dijelaskan lebih lanjut.

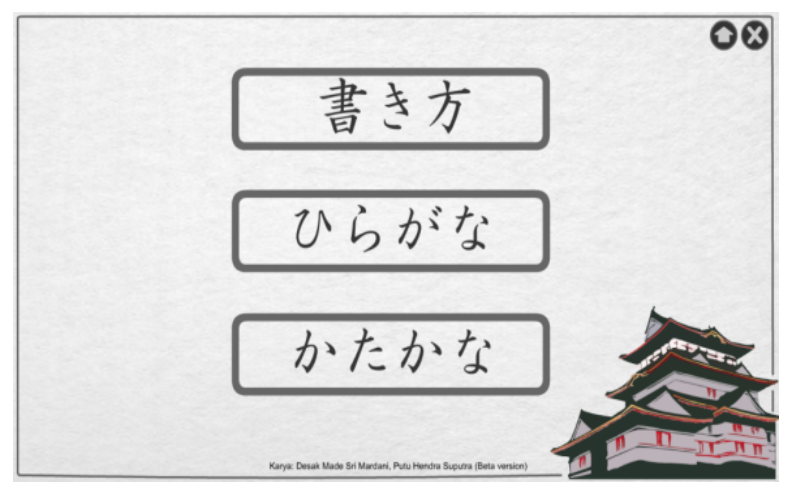

Gambar 3: Tampilan layar. 


\section{1. 書き方 (Kakikata)}

Pada 書き方 dijelaskan penggunaan warna yang berbeda pada masing-masing goresan pembentuk huruf yang digunakan pada media ini. Warna biru digunakan untuk goresan haraimasu, warna hitam untuk goresan tomarimasu, sedangkan warna hijau untuk goresan hanemasu. Dengan penjelasan tersebut, maka pengajar dan pembelajar dapat menggunakan media tersebut dengan mudah.

\section{2. ひらがな (Hiragana)}

Padaひらがな terdapat semua materi terkait huruf Hiragana meliputi silabel dasar, Dakuon, Handakuon, You'on, Chou'on, Sokuon dan penggunaan huruf Hiragana sebagai partikel. Contoh tampilan materi Hiragana seperti terlihat pada Gambar 4.

a. Silabel dasar

Pada bagian silabel dasar dimunculkan keseluruhan huruf dari a sampai n, dimana masing-masing silabel akan ditunjukkan urutan serta goresan pembentuk huruf tersebut.

b. Dakuon, Handakuon dan You'on

Urutan penulisan dan goresan diberikan pada setiap silabel dasar, sedangkan pada Dakuon, Handakuon, dan You'on tidak diberikan lagi. Pada tampilan layar dimunculkan silabel-silabel apa saja yang termasuk dalam kelompok Dakuon, Handakuon, dan You'on.

c. Chou'on dan Sokuon

Pada materi Chou'on, Sokuon, serta contoh kosakata langsung diberikan dalam satu tampilan layar. Hal ini berbeda dengan Dakuon, Handakuon, dan You'on yang terdiri dari banyak silabel sehingga contoh kata dimunculkan pada tampilan layar yang berbeda.

d. Penggunaan huruf Hiragana sebagai partikel

Seperti halnya Dakuon, Handakuon, You'on, Chou'on, dan Sokuon, pada tampilan huruf Hiragana sebagai partikel juga tidak dimunculkan urutan penulisan dan goresan huruf. Pada tampilan layar dimunculkan huruf Hiragana yang menjadi partikel beserta transliterasinya dalam huruf latin (bagian kiri layar), serta penggunaannya dalam sebuah kalimat (bagian kanan layar).

e. Contoh penggunaan huruf dalam kosakata dan kalimat

Pada masing-masing materi (silabel dasar, Dakuon, Handakuon, You'on, Chou'on, Sokuon dan penggunaan huruf Hiragana sebagai partikel) diberikan contoh kosakata dan kalimat. Hal ini memungkinkan untuk melatih pembelajar dalam mengingat huruf melalui kegiatan membaca. Tampilan contoh kosakata dan kalimat berbeda pada masing-masing materi seperti yang sudah dijelaskan pada masing-masing materi. Untuk kosakata dan kalimat yang dimunculkan tidak berbarengan dengan silabel yang dimaksud.

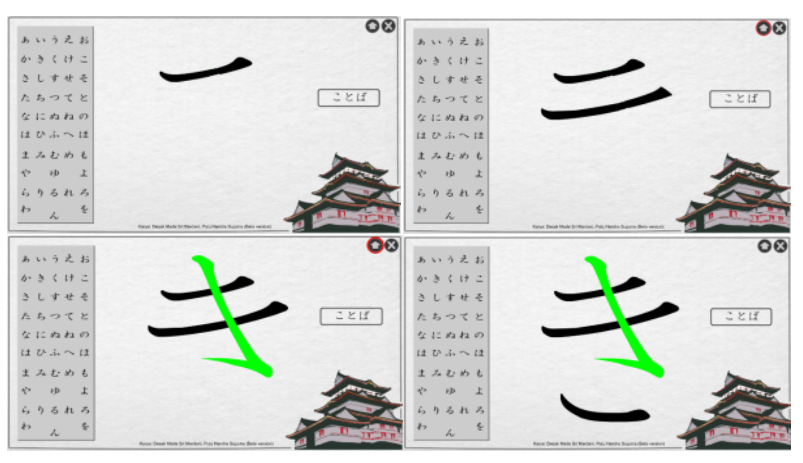

Gambar 4: Contoh tampilan huruf Hiragana

\section{3. かたかな (Katakana)}

Pada かたかな sama halnya seperti ひらがな, terdapat semua materi terkait huruf Katakana meliputi silabel dasar, Dakuon, Handakuon, You'on, Chou'on, dan Sokuon. Contoh tampilan materi Katakana seperti terlihat pada Gambar 5.

a. Silabel dasar

Pada materi silabel dasar, ditampilkan sama seperti pada Hiragana, dimana masing-masing huruf akan ditampilkan urutan penulisan serta goresan yang membentuk huruf tersebut.

b. Dakuon, Handakuon dan You'on

Seperti pada huruf Hiragana, hal yang sama juga dilakukan pada materi Dakuon, Handakuon dan You'on pada huruf Katakana, di mana tidakdiberikan kembali urutan penulisan dan goresan.

c. Chou'on dan Sokuon

Pada materi Chou'on dan Sokuon huruf Katakana sama seperti pada huruf Hiragana, di mana contoh kosakata langsung diberikan dalam satu tampilan layar. Hal ini disebabkan jumlah Chou'on dan Sokuon yang sedikit.

d. Silabel Tambahan

Terdapat kelompok silabel tambahanuntuk mengelompokkan silabel selain silabel dasar, Dakuon, Handakuon, You'on, Chou'on, dan Sokuon. Pada kelompok ini diberikan pula contoh kosakata yang sebagian besar adalah nama orang.

e. Contoh penggunaan huruf dalam kosakata

Pada silabel dasar, Dakuon, Handakuon, You'on, Chou'on, Sokuon dan silabel tambahan diberikan contoh kosakata. Melalui contoh ini pengajar dapat memberikan latihan kepada pembelajar dalam mengingat huruf melalui kegiatan membaca. Selain materi Chou'on, Sokuon, dan silabel tambahan, contoh kosakata diberikan secara terpisah pada layar karena 
jumlah silabel dari masing-masing materi tersebut banyak.
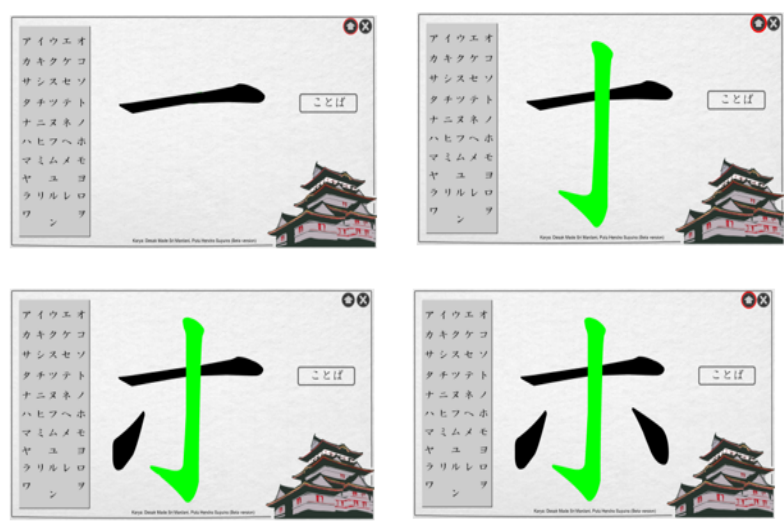

Gambar 5: Contoh tampilan huruf Katakana.

\section{Uji Coba Media Interaktif}

Setelah prototipe dari media disempurnakan, kemudian dilakukan uji coba lapangan dalam skala terbatas terhadap 26 orang mahasiswa yang terdiri dari angkatan yang berbeda (tingkat dua sampai tingkat lima) untuk mengetahui respon pembelajar terbatas pada tampilan media dan kejelasan goresan huruf. Ujicoba terkait efektivitas penggunaan media dalam membantu mahasiswa dalam proses pembelajaran belum dapat dilaksanakan. Adapun hasil analisis data angket seperti terlihat pada Tabel 2 .

Berdasarkan Tabel 2 dapat diketahui bahwa masing-masing indikator yang terdapat dalam penilaian dari media yang dihasilkan mendapat respon sangat positif dari mahasiswa. Berdasarkan tabel juga terlihat bahwa aspek yang paling tinggi mendapatkan respon dari mahasiswa adalah aspek isi dengan respon $95,85 \%$ berada pada kategori sangat positif. Sehingga secara keseluruhan pun media tersebut memperoleh respon yang sangat positif pula dengan nilai 93,24.

Tabel 2: Hasil analisis data angket.

\begin{tabular}{|l|c|l|}
\hline Indikator & Interval & Kategori Respon \\
\hline Aspek Pemrograman & & \\
\hline Kemudahan penggunaan program & $95 \%$ & Sangat Positif \\
\hline Kemudahan memilih menu program & $92 \%$ & Sangat Positif \\
\hline Kemudahan masuk dan keluar dari program & $92 \%$ & Sangat Positif \\
\hline Ketepatan reaksi button (tombol) & $89 \%$ & Sangat Positif \\
\hline Total Respon aspek pemrograman & $\mathbf{9 2 . 3 1 \%}$ & Sangat Positif \\
\hline Aspek Isi & & \\
\hline Goresan pada huruf terlihat jelas & $98 \%$ & Sangat Positif \\
\hline $\begin{array}{l}\text { Penggunaan warna sangat membantu dalam membedakan } \\
\text { Goresan }\end{array}$ & $98 \%$ & Sangat Positif \\
\hline Urutan goresan huruf terlihat jelas & $98 \%$ & Sangat Positif \\
\hline Contoh kosakata sesuai dengan materi & $91 \%$ & Sangat Positif \\
\hline Kejelasan tulisan (huruf Jepang) yang digunakan & $95 \%$ & Sangat Positif \\
\hline Total Respon aspek isi & $\mathbf{9 5 . 8 5 \%}$ & Sangat Positif \\
\hline Aspek Tampilan & & \\
\hline Tata letak huruf dan contoh kata baik & $90 \%$ & Sangat Positif \\
\hline Kesesuaian pemilihan background & $89 \%$ & Sangat Positif \\
\hline Kesesuaian pemilihan ukuran dan jenis huruf & $93 \%$ & Sangat Positif \\
\hline Kesesuaian warna & $\mathbf{9 7 \%}$ & Sangat Positif \\
\hline Kemenarikan tampilan tombol & $\mathbf{9 1 . 3 8 \%}$ & Sangat Positif \\
\hline Total Respon aspek tampilan & $\mathbf{9 3 , 2 4 \%}$ & Sangat Positif \\
\hline Respon keseluruhan & & \\
\hline
\end{tabular}




\section{KESIMPULAN DAN SARAN}

Berdasarkan hasil penelitian, diketahui bahwa media pembelajaran interaktif yang dihasilkan sudah memuat semua materi tentang Huruf Hiragana dan Katakana meliputi: silabel dasar, Dakuon, Handakuon, You'on, Chou'on, Sokuon, penggunaan huruf Hiragana sebagai partikel, serta silabel tambahan pada huruf Katakana. Media juga dilengkapi dengan pemberian kosakata yang masih berada di lingkungan pembelajar, sehingga pembelajar dapat lebih mudah mengaitkan antara huruf dan makna dari suatu kata. Berdasarkan hasil angket terkait respon mahasiswa terhadap media pembelajaran interaktif yang dihasilkan, diketahui bahwa secara keseluruan respon dari mahasiswa tergolong sangat positif. Pada penelitian ini baru sampai pada tahap uji coba lapangan dalam skala terbatas, oleh sebab itu uji coba implementasi dalam pembelajaran sangat penting untuk dilaksanakan.

\section{DAFTAR PUSTAKA}

Elliott, Stephen N. (2000). Educational Psychology: Effective Theaching, Effective Learning, The Mc. Graw-Hill Companies, Inc.: USA.

Ghavifekr, S. \& Rosdy, W.A.W. (2015). Teaching and learning with technology: Effectiveness of ICT integration in schools. International Journal of Research in Education and Science (IJRES), 1(2), 175-191. https://doi.org/10.46328/ijres.v1i2.79

Istiqlal, M. (2017). Pengembangan multimedia interaktif dalam pembelajaran matematika. Jurnal Ilmiah Pendidikan Matematika, 2(1). http://dx.doi.org/10.26877/jipmat.v2i1.1480

Lia, L. (2015). Multimedia interaktif sebagai salah satu alternatif pembelajaran dalam bidang pendidikan sains. Jurnal Inovasi dan Pembelajaran Fisika, 2(2). https://doi.org/10.36706/jipf.v2i2.2614
Listriani, Lispridona, D., \& Silvia, N. (2018). Analysis of difficulties student of class XI IPS SMA Taruna Nusantara in reading Hiragana. CHI'E: Journal of Japanese Learning and Teaching, 6(2), 64-67. https://doi.org/10.15294/chie.v6i2.22595

Maesaroh, S., \& Malkiah, N. (2015). Media pembelajaran interaktif bahasa Inggris pengenalan huruf dan membaca berbasis multimedia untuk Sekolah Dasar. Jurnal Sisfotek Global, 5(1). http://dx.doi.org/10.38101/sisfotek.v5i1.71

Mardani, D.M.S. (2012). Pemanfaatan media visual untuk meningkatkan kemampuan menulis huruf Hiragana dan Katakana. Jurnal Pendidikan dan Pengajaran, 45(3). http://dx.doi.org/10.23887/jppundiksha.v45i3.1836

Mardani, D.M.S., \& Suputra, P.H. (2016, Nopember). Meningkatkan kompetensi guru bahasa Jepang di kabupaten Buleleng melalui pelatihan pembuatan media pembelajaran penulisan huruf Jepang menggunakan animasi flash. Prosiding Seminar Nasional Pengabdian kepada Masyarakat (Senadimas), Sanur, Bali. Diakses dari http://eproceeding.undiksha.ac.id/index.php/senadi mas/article/view/380/267.

Sari, L.K., \& Sasongko, D. (2013). Media pembelajaran interaktif bahasa Inggris untuk siswa Sekolah Dasar kelas II. Seruni-Seminar Riset Unggulan Nasional Informatika dan Komputer, 2(1). http://dx.doi.org/10.0809/seruni.v2i1.583

Susilana, R., \& Riyana, C. (2009). Media Pembelajaran: Hakikat, Pengembangan, Pemanfaatan dan Penilaian. Bandung: Wacana Prima.

Sutedi, D. (2009). Penelitian Pendidikan Bahasa Jepang. Bandung: Humaniora Utama Press.

Thiagarajan, S., Semmel, D., \& Semmel, M. (1974). Instructional Development for Training teacher of Exceptional Children. Indiana: ERIC.

Yamasari, Y. (2010, Agustus). Pengembangan media pembelajaran matematika berbasis ICT yang berkualitas. Seminar Nasional Pascasarjana X-ITS, Surabaya. Diakses dari https://mathmagicedu.wordpress.com/2018/03/15/ pengembangan-media-pembelajaran-matematikaberbasis-ict-yang-berkualitas/. 